\title{
Bridging conflicting ideologies: the origins of American and British occupational therapy.
}

Ruth L. Schemm

Thomas Jefferson University

Follow this and additional works at: https://jdc.jefferson.edu/otfp

Part of the Occupational Therapy Commons

Let us know how access to this document benefits you

\section{Recommended Citation}

Schemm, Ruth L., "Bridging conflicting ideologies: the origins of American and British occupational therapy." (1994). Department of Occupational Therapy Faculty Papers. Paper 55. https://jdc.jefferson.edu/otfp/55

This Article is brought to you for free and open access by the Jefferson Digital Commons. The Jefferson Digital Commons is a service of Thomas Jefferson University's Center for Teaching and Learning (CTL). The Commons is a showcase for Jefferson books and journals, peer-reviewed scholarly publications, unique historical collections from the University archives, and teaching tools. The Jefferson Digital Commons allows researchers and interested readers anywhere in the world to learn about and keep up to date with Jefferson scholarship. This article has been accepted for inclusion in Department of Occupational Therapy Faculty Papers by an authorized administrator of the Jefferson Digital Commons. For more information, please contact: JeffersonDigitalCommons@jefferson.edu. 


\section{LOOKING BACK}

\section{Bridging Conflicting Ideologies: The Origins of American and British Occupational Therapy}

\author{
Ruth Levine Schemm
}

\author{
Key Words: history of occupational therapy • \\ human activities and occupations
}

Occupational therapy practice has bridged two conlradictory value systems for more than 100 years. This article describes the origins of practice ideas in both the United States and Britain and demonstrates that founding members of the occupational therapy profession all shared a core of humanistic beliefs while embracing the emerging paradigm of scientific medicine. The resull bas been an intellectual tension between the biological and the psychosocial aspects of practice. For more than 75 years, occupational therapists stmiggled to balance the art and science of patient care; recent debates on modalities, practice domains, and research priorities indicate that the unifying core of the profession is occupation that considers a person's mind and body.

Ruth Levine Schemm, EdD, OTRL, FAOTA, is Professor and Chairman, Department of Occupational Therapy, Thomas Jefferson University, Room 824 Edison, 130 South Ninth Street, Philadelphia, Pennsylvania 19107.

This arlicle was accepled for publication December 10, 1993.
T This article describes the tension between the arts and crafts ideology and the emerging scientific focus of occupational therapy practice by using the development of American and British occupational therapy during the late 1930 s as an illustration. American leaders were anxious to separate themselves from the lay health "occupation cure" that was widely used during the World War I era and eagerly sought status as an adjunctive aspect of medicine. Although not totally divorced from the ideology of the Arts and Crafts Movement, early occupational therapists strove to make their work therapeutic and scientific. The result was an uneasy alignment of ideas that were not totally congruent. The arts and crafts ideology, reflecting the compelling force of intrinsic creation, was combined with a therapeutic process (occupational therapy) that was developed to make persons with disabilities and idle persons productive. Early therapists were socializing agents, stalwart in their medical beliefs, who compared their occupation cure to medication.

At the turn of the century, British physicians used occupations extensively to rehabilitate injured World War I soldiers. After the war, Dr. David Henderson directed a small department at Gartnavel Hospital, Glasgow, Scotland, but this intervention was not identified as oсcupational therapy until a British physician, Elizabeth Casson, founded Dorset House Residential Clinic in Bristol, England, in 1929. Casson worked for the social welfare movement under the supervision of Octavia Hill and entered medical school when she was 30 years old. Interested in psychological medicine, Casson traveled to America to visit occupational therapy programs and, in effect, imported the profession back to England by starting her own clinic and education program.

Some of the contradictions in modern practice can be traced to this early differentiation between the use of arts and crafts as occupations for invalids and the medically based use of activities. This differentiation explained Casson's trip to America to learn about occupational therapy because ideas from the British Arts and Crafts Movement were the basis of U.S. practice.

Early American occupational therapy was shaped by many popular beliefs, some holistic and some mechanistic. Thus, the contemporary argument-that selected modalities are reductionistic and that the use of arts and crafts is holistic-does not capture the complexity of these turn-of-the-century ideas in which the body was likened to a machine (Dunton, 1915) and arts and crafts were prescribed like a dose of medication (Barton, 1920; Haas, 1922; Tracy, 1914). The practice of skillful occupational therapy cannot be classified merely by the modality used by the therapist. In fact, the therapeutic interaction between patient and therapist must be considered.

\section{The British Arts and Crafts Movement}

On the basis of the thinking of Oxford University don 
John Ruskin, William Morris founded the popular Arts and Crafts Movement, which eschewed machine-made goods, valued handcrafted objects, and celebrated the return to a life that integrated mind and body with soulsatisfying labor that refreshed rather than taxed the person (Boris, 1986; Lears, 1981; Orage, 1907; Tames, 1990). The mind-numbing experience of factory work attracted British and American followers to Morris' ideas because he articulated their disdain for the materialism of industrialized society. Although Morris was a poet, critic, and devoted socialist, his audience was far more taken with his craftsmanship and aesthetic wisdom than with his social criticism. A prodigious worker, Morris designed and made furniture, fabric, tapestries, stained-glass windows, and hand-bound and illuminated books ("William Morris," 1901). However, his social criticism was embraced only by a small and scattered group of followers among British leftists (Lears, 1981; Orage, 1907; Wiener, 1976). This situation frustrated Morris, and, at the height of his popularity in 1888, he attacked the Arts and Crafts Movement for placing self-interests ahead of social change (Lears, 1981; Orage, 1907; Wiener, 1976; "William Morris," 1901).

Morris' speeches and lectures resulted in few changes to the British social order, and his influence waned during the last years of his life, although he continued to work as a socialist organizer (Lears, 1981; Wiener, 1976). The influence of the Arts and Crafts Movement also declined after Morris's death in 1896 because no other arts and crafts leader combined Morris' artistic talents, dogged determination, and interest in improving society (Orage, 1907). Morris's criticism of the British Arts and Crafts Movement proved accurate because fellow artisans fought for the opportunity to produce quality work rather than participate in a movement designed to improve society.

\section{The American Arts and Crafts Movement}

Many Americans were interested in the Arts and Crafts Movement, which lasted from 1895 to 1920 and shaped the values of many occupational therapy leaders. John Ruskin, the Oxford University don who influenced William Morris, was widely read by prominent American social reformors, and the Arts and Crafts Movement swept across the continent so that every major community established an arts and crafts organization. The ideas discussed in these clubs struck a responsive chord in socially advantaged Americans, who appreciated the benefits of capitalism but found its excesses (materialism fed by abject poverty among the lower classes) unnerving (Lears, 1981).

Searching for ways to improve society, members of the American Arts and Crafts Movement developed programs that used art, crafts, music, and dance to socialize less accepted members of society such as disabled, men- tally ill, impoverished, and underachieving persons in insane asylums and manual training programs. A well-designed and well-executed arts and crafts project could provide an opportunity to foster discipline and effective worker roles (Boris, 1986; Hull House Bulletin, 1902; KapJan, 1987; Simkhovitch, 1906).

Among early Arts and Crafts proponents, the reading of Ruskin, Morris, and other like-minded authors became popular, and followers extolled the benefits of handmade goods that were well-designed, created from natural materials, and were functionally useful. George Barton, one of the founders of the American Occupational Therapy Association (AOTA), served as Secretary of the Boston Arts and Crafts Society in 1904, embraced the ideals of the Arts and Crafts Movement, and worked at Kelmscott Press in London, where Morris did much of his bookbinding and calligraphy work. Barton applied these ideas to himself when he developed paralysis of his left side after part of his left foot was amputated; he opened a workshop, Consolation House, to demonstrate the power of using goal-directed activities or occupations to cure persons with illness or disabilities.

\section{Occupation Therapy as a Medical Profession}

Americans were not interested in Morris' socialist ideas; however, they eagerly applied the aesthetic aspects of the Arts and Crafts Movement to persons in settlement houses, hospitals, and home programs from 1880 to 1920. Demand for these programs accelerated during World War I because the number of war-injured men mounted, and programs offered in France, England, and Canada were discussed in newspaper and magazine articles (Fecleral Board for Vocational Education, 1918). Major General Robert Jones, a prominent orthopedic surgeon, was the first British physician to develop an occupation treatment program. Jones was directed to investigate the types of cases that required comprehensive care where "every therapeutic department could be represented and each member of the staff should be allotted the work for which he was fitted" (Jones, 1918a). Throughout England, Jones found evidence of war injuries that were poorly treated, neglected, and painful. With the approval of his superiors, Jones opened a 250-bed hospital in Liverpool and found that the need was so great that accommodations were expanded to 20,000 beds all over the United Kingdom (Jones, 1918a). Jones' program featured comprehensive medical care in which surgeons followed their assigned cases; occupations, therapeutic exercise, and vocational training were included in treatment.

In the United Stc.tes, a network of enlightened physician leaders like Adolf Meyer, Edgar King, Joel Goldthwait, Herbert Hall, and Elliot Brackett continued to promote the occupation cure. The need for an experienced, educated professional trained specifically to teach arts 
and crafts was articulated by Arthur Crane (1921/1972), Herbert Hall (1923), and Willam Rush Dunton (1928) These leaders were familiar with the comprehensive treatment organized by Robert Jones and combined Jones' ideas with their own treatment experiences. In 1918, under the direction of Surgeon General William Crawford Gorgas, comprehensive services were developed for war-injured U.S. veterans (Federal Board for Vocational Eclucation, 1918; Gritzer \& Arluke, 1985; McDaniel, 1968). 'The occupation cure was offered before vocational education. For every " 1 million soldiers sent to the front, 100,000 would recurn, and 20,000 would require vocational reeducation" (Federal Board for Vocational Education, 1918, p. 69); thus, occupation workers were in great demand.

\section{Occupation Cure and Curative Occupations}

From 1890 to 1920 , two ideas formed the foundation of the occupation cure: (a) the creation of a well-designed product (arts and crafts ideology) and (b) the graded, therapeutic process (the medical influence) of participating in an activity that promoted healing, required action, and promoted feelings of competence.

Occupation workers who embraced the arts and crafts ideology believed that quality supplies, good design, and concern for craftsmanship were curative, so there was minimal need to match patient interests with a special project. Craftsmanship alone was considered a significant motivator. Arts and crafts programs focused on producing a well-made, hand-constructed product that was pleasing to the eye and satisfying to the soul of the creator. The medically influenced occupation workers were more interested in process rather than the final product (Barton, 1919; Brackett, 1918; Crane, 1921/1972; Myers, 1948). Goals were prescriptive, such as reducing pain or increasing range of motion to the point of fatigue, and therapy was an adjunct to effective medical treatment.

The intermingling of process and product was evident in development of the occupation cure in the physical reconstruction or rehabilitation of war-wounded soldiers. As men returned from the front lines of battle, "more than $50 \%$ of those with serious battle casualties were left with chronic conditions that required comprehensive restoration" (Ireland, 1927, p. 552). In a letter, Jones described the disorganized medical, restorative, or rehabilitation care offered at the beginning of the war that left the discharged men "totally unfitted either for military or civilian life. These men promised to become foci of seething discontent, and at that time a menace to successful recruiting" (Jones, 1918b).

Jones went on to describe the comprehensive medical and rehabilitative care he helped to organize in England. This care began with a trained orthopedic surgeon who made the diagnosis, performed or assisted at an operation if needed, and, most important, took charge of subsecuent treatment. "Trcatment usually consisted of massage, hydrotherapy, electrotherapy, exercises, and work in some curative vocation such as fishnet making, basket work, wood turning, jigsaw work, cabinet making, carpentry, forestry, or farming" (Ireland, 1927, p. 553).

Through the collaborative sharing of icleas on how to properly train orthopedic surgeons, provide adequate postsurgical care, and offer bedside, ward, and workshop programs for the injured soldier, the American and British reconstruction efforts were closely allied. In the United States, physical reconstruction was defined as "complete medical and surgical treatment, carried to the point where maximum functional restoration, mental and physical has been secured" (Crane, 1921/1972, p. 1). The medical use of occupation diverted the injured, mentally ill, or sick person from suffering and offered an alternative to self-centered thoughts. "In a short period of time, under rush conditions, in a new field, the Surgeon General succeeded in establishing 50 hospital schools with 2,500 instructors and equipment for providing instruction in 150 occupations to 100,000 men" (Crane, 1921/1972, p. 43)

From 1918 to 1921, in the training programs for U.S. veterans, there were no standardized rules guiding therapists to focus on product or process. Arts and crafts teachers joined in the medicalization of a popular lay health movement, and physicians interested in arts and crafts used icleas about occupation in their treatments. In ideal circumstances, a series of projects was initiated at the bedside or on the ward after a recuperating soldier was interviewed by a psychologist. Reconstruction aides, who were experienced teachers, offered diversional activities by using their past education, personal charm, tact, enthusiasm, and curiosity to engage the soldier's interest in a chain of increasingly complex activities that were finally tied to vocational interests (Crane, 1921/1972). Bedside occupation work was complex and required skillful intervention. As the soldiers recovered, they were transferred to vocational teachers for job training (Brackett, 1918; Crane, 1921/1972). Vocational teachers were usually craftspersons.

There were two problems dominating occupation treatment. The first was the pressure of having so many patients, so few supplies, and an average of only 30 days of convalescence in the rehabilitation programs for the U.S. veterans. The demand for therapist attention led to the development of a scorecard that described essential, highly desirable, and relatively desirable traits of treatment. Essential traits of treatment were those activities that promoted the patient's recovery and "lead the man's thoughts out from the wards to the shop, to the school room and to future activities" (Crane, 1921/1972, p. 54). Highly desirable traits of treatment were those activities that required little time from the instructor and propor- 
tionately greater time from the patient so that the project permitted short periods of instruction and long periods of unsupervised activicy. Relatively desirable traits of treatment involved the appeal of the craft and the materials to the patient.

The second problem involved craftspersons such as weavers, potters, and carpenters employed in workshops such as those owned by physicians Herbert Hall and Edgar King. As artisans working in workshops and clinics where a quality product was sold for operating funds, the craft teachers had to make sure that the final product was worthy of sale. The pressure to stay solvent forced craftspersons-rehabilitation workers to do much of the work in certain clinics. Hall (1922) explained that staff members "think for the patient and complete for him all the parts of the work he would not be likely to accomplish as well as [sic] himself" (p. 244).

U.S. occupational therapy founders could not resolve whether the focus of therapy should be on process or product. Some examples of this dilemma are Barton's claim that an occupation could produce a similar effect to that of every drug in materia medica (Barton, 1920). Conversely, Haas (1922), the director of the Occupation Department at Bloomingdale Hospital, New York, believed that occupations had to be "interesting, . . controlled and the patient perform at least four-fifths of all the work involved" (p. 446). Earlier, Dunton had claimed that occupational therapy justified itself as a "medical agent" (Dunton, 1918a, p. 91), although Tracy (1912) quoted Dewey and stated that occupation was not "busy work" (p. 13) and had to be used to create a "non-sick place" for the patient (p. 4) so that interest could be "aroused and fanned into real enthusiasm" ( $p .6)$. In 1914. Tracy maintained that occupations - like other remedial treatments such as exercise, massage, hydrotherapy, and lightrays - possess "true therapeutic value" and share the same properties as medication that can be classified into like "categories."

\footnotetext{
Just as the physician runs through the list of stimulants and rads-strychnne, caffeme, adrenalin - . so he may read down the list of stimulating occupations-water color painting, cloll clressing, designing of coslumes, paper folding. Making his selecrion from these. he wurns to the nurse to order its administration. (Tricy. 1914, p. 386)
}

Ultimately, the group of occupation workers who shared an interest in linking their ideas to medicine formed a professional association, the National Society for the Promotion of Occupational Therapy, which later became AOTA. The first president of the association, George Barton, summarized the group's beliefs by stating that "reeducation rests on the making of a man not an object" (Barton, 1919, p. 61). The American founclers of the profession worked to establish boundaries between the more global and common use of arts and crafts as a mind diversion and the more medically directed therapy of- fered by occupational therapists.

\section{Defining Curative Occupations}

The curative use of occupation was a developing concept. Johnson attempted to clarify various definitions of the concept and stated that "terms in common use which relate to occupation therapy are very generally applied with a loose interpretation" (1919, p. 221). Occupation in military hospitals began at bedside, moved to ward activities, and included academic subjects, shops and trades, commercial courses, agriculture, and recreational activities. The most popular activities were work with textiles (weaving); reed, cane, and fiber work; and woodworking. The number of injured men enrolled in all services that used reconstruction aids, vocational workers, and teachers from January to June 1919 totaled 249,474 (Crane, 1921/1972).

Dunton (1918a, 1918b) identified three types of occupation: (a) occupations for invalids that diverted the patient from pain and were performed at bedside, (b) occupational therapy that restored mental and physical function, and (c) vocational therapy that restored function to persons with disabilities. Johnson (1919) concurred and discussed a continuum of care that began at bedside where the occupation worker had knowledge of medical conditions (occupations for invalids), progressed to formal occupations where education and moral issues were aclded to therapeutic goals, moved on to outpatient workshops where medical supervision was still available, and finally culminated in a curative workshop where a specialist in one or more academic, industrial, or commercial subjects would be combined with knowledge of vocational education. "Poor results" were a consequence of "the lack of logical methods of teaching" rather than a lack of knowledge of subject matter (Johnson, 1919, p. 222)

Mere engagement in a well-designed occupation was not necessarily therapeutic; rather, the choice of activity required knowledge of medical conditions, time to consider activity options, the ability to plan and set up the patient for a successful experience, and attention to safety, fatigue, and patient abilities (Hall, 1923; Johnson, 1919; Tracy, 1912). Apparently, the early notion that a craft would be therapeutic in and of itself did not prove to be accurate.

[t will always be a problcm to keep a definite midkle path berwcen the nursing and the reaching aspects of this work. "Thcrapeutics have uo ofen been an excuse for poor craftsmanship and arivial results. On the other hand, instructors whose sole training has bcen that of the craftsman or has been in educational and vocalional fields outside of the hospital would naturally and quite unconsciously put too strong an emphasis upon the educational and economic sides. It is this abilicy to keep a fine balance between these two things which, after all, will prove the real understanding and efficiency of che directors of occupation therapy. (Johnson, 1919. p. 223) 


\section{The Emergence of British Occupational Therapy}

The use of occupations to treat injured patients continued in a few programs in Great Britain during the 1930s, but most occupation programs were confined to mental hospitals. Furthermore, the personnel conducting these programs lacked professional status and had no formal relationship to medical rehabilitation and vocational training.

The development of the profession of occupational therapy in Grcat Britain is therefore rightfully credited to Elizabeth Casson (1932), an energetic physician who entered medical school after working as a social worker. Following American ideas and knowledge of the arts and crafts ideology, Casson championed the initiation of occupational therapy. In 1926, during a 2 -week vacation in America, Casson toured occupational therapy programs and visited Bloomingdale Hospital and the Boston School of Occupational Therapy (Casson, 1939). She returned to England to search out existing occupation or craft programs and initiated occupational therapy at Virginia Water, a psychiatric facility, by using the talents of two craftswomen. Casson left the hospital to found a residential clinic at Dorset House on Clifton Down, Bristol, England. Casson was committed to full-time patient care, and from this idea the Dorset House School of Occupational Therapy grew (Casson, undated, p. 4). Medical control of occupational therapy, standardized education programs, and habit training for patients were concepts that Casson imported from America and used in the development of British occupational therapy. She also adapted the combination of arts and crafts ideology and therapy based on medical prescription to British occupational therapy.

Casson believed that the products made by patients were important. "There should be an aim at producing beautiful finished work, for only by doing her best work will the patient recover her right attitude to life" (1941, p. 41). On the other hand, Casson's commitment to therapeutic gains was evident when she addressed the problems of an orthopedic patient. "Massage and remedial exercise can be extraordinarily dull to a patient with a stiff knee while a bicycle saw and intricate jig-saw puzzle to cut will produce a quicker result" (Casson, 1938, p. 268). Casson's views were consistent with those of American occupational therapy leaders such as Dunton, Barton, and Hall. She described the difference between a program directed by a trained occupational therapist and one directed by an arts and crafts teacher:

Unfortunately, even in some of the best English mental hospitals, an idea is prevalent that any one who is pleasant and good-tempered and who is capable of teaching hasket and rugmaking may be regarded as being able to start an occupational therapy department but although occupation is thus provided, therapy is usually absent. (Casson, 1932. p. 39)

Casson fought for acceptance of the occupational therapy profession through the encouragement of a government regulatory agency called the Board of Control and by enlisting the assistance and support of fellow physicians Newman Neild and Carey Coombs of the General Hospital of Bristol. Acceptance by the British medical establishment was slow. For example, the Southmead Health Committee took more than 5 years to accept Casson's offer to provide occupational therapy services without compensation, even though the medical superintendent of Southmead Hospital, Dr. Phillips, supported the idea. In 1937, 920 patients received occupational therapy services under Casson's supervision, and her efforts began to take effect (Casson, 1938, p. 266). The Allendale Curative Workshop (Clifton, Bristol) opened in 1939 and offered treatment for orthopedic injuries, including fractures, with graded craft activities (Casson, 1941). By 1939, World War II had begun, and "the Organizers of the Emergency Medical Service of the Ministry of Health decided to entrust the training of occupational therapists to imple. ment wartime rehabilitation to Dorset House" (Casson, 1947 , p. 304). The pressure to produce nceded therapists in a short time was complicated by the bombing of Bristol, so the program was moved to Barnsley Hall E.M.S. Hospital at Bromsgrove. Members of this emerging profession struggled for a place in the medical society hierarchy as rehabilitation emerged as a specialty field.

The tension between the "scientific" aspects of occupational therapy and crafts was noted by E. M. MacDonald, an occupational therapist, who believed that "trade prejudice" complicated the growth of the profession because of the therapists' choice of limiting treatment modalities to crafts. "This was frustrating to those who had to carry out the prescriptions, and gave quite a wrong emphasis to the occupational aspect of the treatment" (MacDonald, 1976, p. 9).

\section{British and American Occupational Therapy - Emerging Issues and Problems}

Casson (1940) based the British occupational therapy profession on American ideas: the importance of specific training for occupational therapists, the need for medical supervision and prescription, the treatment of more acutely ill patients, and the need for research to explain the success of occupational therapy. Although Casson and American leaders remained dedicated to arts and crafts ideology, they began to rely more heavily on pathokinesiology and scientific reasoning to justify treatment. The need to emphasize the scientific aspects of occupational therapy was clear to many therapists, as shown by the reference to the "scientific" therapy groups mentioned in the annual report of a chief therapist (Letter to Flise Spuehler from S. Metz Miller, Norristown State Hospital Superintendent, 1929; Draft of submission for Annual Report, Elise Spuehler, Norristown State Hospital, year ending June 1, 1931 [R.L. Schemm, private collection]). Occupational therapists have bridged two contradic- 
tory value systems for more than 75 years. The ability to combine the biomedical aspects of patient illnesses with the humanistic values of the Arts and Crafts Movement requires complex patterns of integrative treatment planning. This skill is an asset in today's health care arena where the limitations of scientific medicine encourage practitioners to emphasize the art of patient care. Occupational therapists who have struggled with ways to balance the scientific and artful aspects of practice can guide other professionals to develop more integrative health services.

\section{Summary}

This article traces the conflicting values that shaped both American and British occupational therapy by comparing the medical and humanistic origins of each. Early therapists did not embrace a unified value system; rather, they amalgamated biomedical beliefs with the humanistic values inherent in the Arts and Crafts Movement. The recent debate on physical agent modalities and practice domains can be traced to the profession's early struggle to define practice.

\section{Acknowledgments}

I acknowledge the support of St. Loyes School of Occupational Therapy, Exeter, Devon, United Kingdom, during a 1989-1990 research fellowship, and the support of Dr Rita Goble, Principal, and the faculty and staff members. The following persons helped me to find important references used in the development of this article: Kathleen Reed, PhD. OTR, MIS, FAOTA. Colleen Beatty, OrRs, and Sharon Gutman, Otrr.

This article was presented to members of the Written History Committee during a meeting that commemorated the 75th Anniversary of AOTA, at the 72 nd Annual Conference of the American Occupational Therapy Association, Houston, Texas, March 1992.

\section{References}

Barton, G. (1919). Teaching the sick Philadelphia: Saunders.

Barton, G. (1920). Inoculation of the bacillus of work. Modern Hospital, 8, 399-403.

Boris, E. (1986). Art and labor: Ruskin, Morris and the craftsman ideal in America. Philadelphia: Temple University Press.

Brackett, E. G. (May 21, 1918). Letter to Joel Goldthwait. Surgeon General's Office, 112 Record Group, Box 431. Washington, DC: National Archives

Casson, E. (undated). The storv of the Dorset House School of Occupational Therapy (1930-1949). Bristol, England: Dorset House School of Occupational Therapy.

Casson, E. (1932). Occupational therapy as a profession. Mental Welfare, 13, 39-43.

Casson, E. (1938). Some experiences in occupational therapy. Medical Press and Circular, 197, 265-268.

Casson, E. (1939). 'The value of occupational therapy. Medical Press and Circular, 198, 101-103.

Casson, E. (1940). Occupational therapy as a branch of rehabilitation medicine. British Journal of Pbysical Medicine, 3, 221-225

Casson, E. (1941). Forty cases treated at Allendale Curative Workshop. Lancet, 1, 5-16.

Casson, E. (1947). Occupational therapy in Great Britain. Journal of American Medical Woman's Association, 2, 303-305.

Crane, A. G. (1972). Education for the disabled in war and industry. New York: AMS. (Original work published 1921 by Teachers College, Columbia University, Contributions to Education, No. 110).

Dunton, W. R. (1915). Occupational therapy: A manual for murses. Philadelphia: Saunders.

Dunton, W. R. (1918a). The principles of occupational therapy. Public Healtb Nursing, 10, 316-331.

Dunton, W R. (1918b). Rehabilitation of crippled soldiers and sailors. Maryland Psychiatric Quarterly, 7, 85-102.

Dunton, W R. (1928). Prescribing occupational therapy. Springfield, IL: Charles C Thomas.

Federal Board for Vocational Education. (1918). Vocational rebabilitation of disabled soldiers and sailors. (Senate Document No. 166). Washington, DC: Government Printing Office. Gritzer, G., \& Arluke, A. (1985). The making of rebabilitation: A political economy of medical specialization, 1890 1980. Berkeley, CA: Universicy of California Press.

Haas, I. J. (1922). Crafts adaptable to occupational needs: Their relative importance. Archives of Occupational Therapy, I(6), 443-455.

Hall, H. J. (1922). Editorial: The medical workshop. Archives of Occupational Therapy, 1(3), 243-245.

Hall, H. J (1923), O.T - A new profession. Concord, MA: Rumford Press.

Hull House Bulletin. (1902), Semi-Annual Report. V. Chicago: Hull House |Available in the Peace Collection, Swarthmore College Library, Swarthmore, PA]

Ireland, M. W. (1927). Surgery: The Medical Department of the United States Army in the World War Washington, DC: Government Printing Office.

Jones, R. (1918a). Letter written to Sir Alfred Keogh. Director General, England. Surgeon General, Record Group 112, Box 431. Washington, DC: National Archives.

Jones, R. (1918b). Letter written to Sir George Makins, President Roval College of Surgeons, Liverpool, England. Surgeon General, Record Group 112, Box 431. Washington, DC: National Archives.

Johnson, S. C. (1919). Occupational therapy. Modern Hospilal, 12, 221-223.

Kaplan, W. (1987). The art that is life: In America: 1875-1920. Wilmington, MA: Acme Publishing, Boston Museum of Fine Arts.

Lears, J. T. J. (1981). No place of grace. New York: Pantheon.

MacDonald, E. M. (Ed.). (1976). Occupational therapy in rebabilitation. Baltimore: Williams \& Wilkins.

McDaniel, M. I. (1968). Occupational therapists before World War Il (1917-1940). In R. S. Anderson (Ed.), Army Medical Specialist Corps. Washington, DC: Office of the Surgeon General.

Myers, C. M. (1948). Pioneer occupational therapists in World War I. American Journal of Occupational Therapy, 2, 208-215

Orage, A. R. (1907). Politics for craftsmen. Contemporary Review, 91, 787-788.

Simkhovitch, M. K. (1906). Handicratts in the city: What their commercial significance is under metropolitan conditions. The Craftsman, XI(3), 363-365.

Tames, R. (1990). William Morris Bucks, UK: Shire 
Trace, S. E. (1912). Studies in incalid occupation: A manual for nurses and atrendants. Boston: Whitomb \& Barrows.

Tracy. S. E. (1914). The place of invalid occupation in the general hospital. Wodern Hospital. II, 386-387

Wiener, M. (1976). The mvth of William Morris. Albion, 8 $67-82$.

William Morris. (1901). Crafisman, 1, 1-14́.

Body-conforming support OLYMPIC VAC-PACS

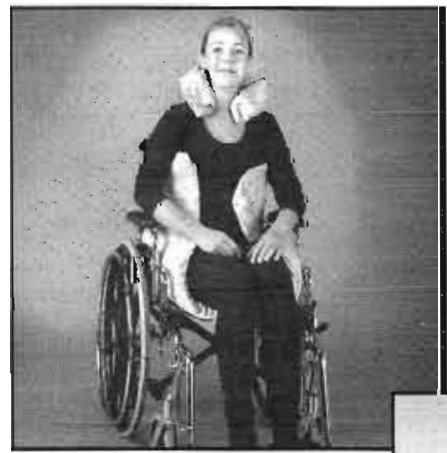

Soft, vinyl pads filled with tiny plastic beads. When air is removed with vacuum pump, the Vac-Pac becomes firm and holds exact molded shape. Squeezing valve allows air back in and Vac$\mathrm{Pac}$ is ready for reuse.

Nine sizes available for any positioning requirement.

\section{OCCUPATIONAL MEDICINE PRACTICE IN PHILADELPHIA}

The Franciscan Health Care System has an opportunity available for a physician specializing in Occupational Medicine. In the heart of Philadelphia, this unique opportunity is with St. Agnes Hospital's million dollar Industri-Care facility. This position offers a strong financial package including salary, productivity bonus and all customary benefits. If you are interested in learning further details, please send your Curriculum Vitae to:

\section{Richard Gormley} Jackson and Coker

115 Perimeter Center Place, Suite 380 (14092) Atlanta, Georgia 30346

Fax 404-399-4604

Phone 1-800-272-2707 ext. 14092 